\title{
KEEFEKTIFAN AUDIT INTERNAL PEMERINTAH DAERAH
}

\author{
Hadi Mahmudah dan Bambang Riyanto, LS. \\ Fakultas Ekonomi Universitas Islam 45 Bekasi dan Fakultas Ekonomika dan Bisnis \\ Universitas Gadjah Mada \\ Email: hadimahmudah@gmail.com
}

\begin{abstract}
This study examined the effectiveness of internal control system, management support, and audit professionalism on internal audit effectiveness of local government. The sample consists of 39 regional inspectorates of six provinces in Indonesia. By using multiple regressions, this study found that internal control system and management support has positive impact on the effectiveness of the internal audit. However, there is no support for the audit professionalism on internal audit effectiveness. This study enriches existing research related to the effectiveness of the internal audit and emphasis the importance of internal control systems in local government.
\end{abstract}

Keywords: internal control system, management support, audit professionalism and the effectiveness of the internal audit.

Abstrak: Penelitian ini menguji efektifitas sistem pengendalian intern, dukungan manajemen dan audit professionalism terhadap keefektifan audit internal. Sampel dalam penelitian ini adalah 39 Inspektorat Daerah dari enam Provinsi. Penelitian ini menggunakan regresi berganda untuk menganalisis data. Hasil penelitian menunjukkan bahwa sistem pengendalian intern dan dukungan manajemen berpengaruh secara positif terhadap keefektifan audit internal. Penelitian ini gagal memberikan bukti empiris audit professionalism berpengaruh terhadap keefektifan ${ }^{1}$ audit internal. Penelitian ini memperkaya penelitian yang sudah ada terkait keefektifan audit internal dan penekanan pentingnya sistem pengendalian intern di pemerintah daerah.

Kata kunci: Sistem pengendalian intern, dukungan manajemen, audit professionalism, keefektifan audit internal pemerintah daerah.

\section{PENDAHULUAN}

Laporan keuangan pemerintah daerah mempunyai dua tujuan utama yaitu untuk akuntabilitas dan pengambilan keputusan (Ryan et al. 2002). Akuntabilitas merupakan salah satu pilar good governance. Menurut The National Committee of Governance Policy (2010) implementasi dari prinsip good governance akan berkontribusi terhadap peningkatan kesejahteraan sosial, membuat lingkungan bisnis yang kondusif, meningkatkan kekuatan tawar (bargaining power) dan mencegah dari kecurangan yang terjadi di pemerintah.

${ }^{1}$ Penelitian ini didanai oleh In search of balance kerjasama Agder University Norwegia dan UGM Indonesia. 
Proses audit penting untuk memastikan akuntabilitas laporan keuangan pemerintah daerah (Aikins, 2012). Di pemerintah baik pusat atau daerah terdapat audit internal dan audit eksternal. Auditor internal pemerintah daerah adalah Inspektorat dan Badan Pengawasan Keuangan dan Pembangunan (BPKP), sedangkan auditor eksternal adalah Badan Pemeriksa Keuangan (BPK). Menurut Prawitt et al. (2008) fungsi audit internal yaitu fokus pada peningkatan laporan keuangan melalui tingkat kepatuhan standar. Fenomena di Indonesia khususnya di pemerintah daerah yaitu sedikit sekali laporan keuangan pemerintah daerah yang mendapatkan catatan wajar tanpa pengecualian dari BPK. Ikhtisar hasil pemeriksaan semester (IHPS) 2 tahun 2013 yang dikeluarkan BPK menunjukkan bahwa hanya 6\% laporan keuangan pemerintah daerah (LKPD) yang mendapatkan opini Wajar Tanpa Pengecualian (WTP). Dalam IHPS tersebut juga dijelaskan bahwa terdapat temuan 1.367 kasus, yang terbagi atas 568 kasus karena kelemahan sistem pengendalian akuntansi dan pelaporan, 549 kelemahan sistem pengendalian pelaksanaan anggaran pendapatan dan belanja dan 250 kasus karena kelemahan struktur pengendalian intern sistem pengendalian intern (IHPS BPK, 2013).

Fenomena di atas menunjukkan bahwa audit internal belum efektif. Tujuan dari penelitian ini adalah menguji faktor faktor yang berpengaruh terhadap keefektifan audit internal. Penelitian ini diharapkan memberikan kontribusi dengan memperkaya literatur terkait dengan keefektifan audit internal di sektor publik khususnya di pemerintah daerah dengan menguji faktor-faktor yang berpengaruh terhadap keefektifan audit internal. Audit internal merupakan penjaga gawang dari tujuan organisasi dimana salah satu tugas audit internal mengevaluasi sistem pengendalian intern. Keefektifan audit internal memiliki peran dalam mencapai tujuan organisasi dalam hal ini pemerintah daerah (Aikins, 2012; Badara dan Saidin, 2013; Kidwell dan Lowensohn, 2011; Mihret et al. 2010). Fungsi dari audit internal di pemerintah yaitu untuk menilai keefektifan dari penggunaan sumberdaya keuangan melalui identifikasi kebocoran, ketidakefektifan dan kecurangan anggaran dan memberikan rekomendasi untuk meningkatkan efisiensi operasional dan menaikkan kinerja Instansi (Aikins, 2012).

Penelitian terdahulu menggunakan beberapa pendekatan untuk meneliti keefektifan audit internal. Twaijry et al. (2003) mengadopsi International standards for professional practice of internal auditing (ISSPIA) sebagai petunjuk untuk meneliti keefektifan audit internal. Peneliti yang lainnya seperti Arena dan Azone (2009; 2010), Cohen dan Sayag (2010) Mihret dan Yismaw (2007) dan Mihret et al. (2010) mengembangkan model untuk menentukan keefektifan audit internal. Beberapa peneliti mengembangkan model tetapi belum diuji secara empiris yaitu Badara dan Saidin (2013), Endaya dan Hanefa (2013) dan Mihret et al. (2010). Penelitian tentang keefektifan audit internal menurut literatur sangat sedikit, menurut beberapa peneliti karena kurangnya perhatian yang cukup yang disebabkan oleh teori (Endaya dan Hanefah, 2013; Mihret et al. 2010 dan Swinkels, 2012) dan keefektifan merupakan area baru dalam penelitian di audit internal (Sarens, 2009).

Beberapa penelitian telah mencoba meneliti faktor faktor penentu keefektifan audit internal. Al-Twaijry et al.meneliti keefektifan audit internal di perusahaan Saudi Arabia. Hasilnya audit internal di Saudi Arabia tidak efektif, audit internal fokus pada kepatuhan dibandingkan dengan audit kinerja, kekurangan sumberdaya dan staf yang qualifie, dan tingkat independensinya rendah. Mihret dan Yismaw (2007) mengidentifikasi beberapa faktor yang dapat berdampak signifikan terhadap keefektifan audit internal di sektor publik Ethiopia. Beberapa faktor tersebut yaitu kualitas audit internal, dukungan manajemen, pengaturan organisasi dan atribut auditee. Hasil penelitian Mihret dan 
Yismaw (2007) mengindikasikan bahwa kualitas audit internal dan dukungan manajemen memiliki hubungan signifikan terhadap keefektifan audit internal. Hasil penelitian Mihret dan Yismaw ini konsisten dengan Cohen dan sayag (2010) yang menemukan bahwa kualitas kerja audit internal, dukungan manajemen dan independensi organisasi sebagai faktor-faktor berhubungan signifikan terhadap keefektifan audit internal.

Penelitian Arena dan Azone (2009) mencoba untuk memahami organisasi sebagai drivers dari keefektifan audit internal. Mereka menggunakan tiga variabel untuk menentukan keefektifan audit internal yaitu karakteristik dari tim audit internal, proses audit dan keterlibatan komite audit dalam aktivitas audit. Ussahawanitchakit (2012) menemukan bahwa keefektifan audit di pengaruhi oleh orientasi etis, penalaran moral, dan profesionalisme audit.

Penelitian ini merupakan replikasi penelitian dari Cohen dan Sayag yang meneliti keefektifan audit internal organisasi sektor publik dan privat di Israel. Mereka menggunakan beberapa variabel yaitu professional proficiency of internal auditors, kualitas kerja audit, independensi organisasi, career dan advancement dan dukungan manajemen puncak sebagai faktor- faktor yang mempengaruhi keefektifan audit internal. Hasilnya dukungan manajemen puncak dan independensi organisasi sebagai penentu keefektifan audit internal di Israel. Peneliti menambahkan variabel sistem pengendalian intern karena menurut Badara dan Saidin (2013) belum ada penelitian sebelumnya yang menguji sistem pengendalian intern terhadap keefektifan audit internal terutama di pemerintahan daerah. Badara dan Saidin (2013) mengembangkan model dampak sistem pengendalian intern terhadap keefektifan audit internal tetapi belum diuji secara empiris. Sistem pengendalian intern telah terbukti secara empiris berhubungan positif terhadap keefektifan audit internal di sektor perhotelan Yunani (Karagiorgos, et al. 2011). Sawalqa dan Qtish (2012) juga menemukan bahwa sistem pengendalian intern berpengaruh terhadap keefektifan program audit.

Penelitian terdahulu melihat keefektifan audit internal dari persepsi auditor eksternal Coram et al. (2008), manajemen (Arena dan Azzone, 2009; Cohen dan Sayag, 2010; Yee et al. 2008), dan fokus pada perusahaan, bank, hotel dan sedikit di sektor publik sehingga menimbulkan kesenjangan. Penelitian ini mencoba menutup kesenjangan yang ada dari penelitian terdahulu dengan menguji secara empiris pengaruh sistem pengendalian intern, dukungan manajemen, audit professionalism terhadap keefektifan audit internal di pemerintah daerah dari persepsi auditor internal. Alasan menggunakan auditor internal karena auditor internal akan mendeteksi kelemahan sistem pengendalian intern sebelum kelemahan itu ditemukan oleh auditor eksternal dan sektor publik khususnya pemerintah daerah karena banyaknya pemerintah daerah yang belum mendapatkan opini WTP dari BPK. Selain itu, penelitian ini mempertimbangkan saran Kidwell dan Lowensohn (2011) yang menyatakan bahwa pengendalian internal di sektor publik memiliki sedikit perhatian dan patut dipertimbangkan dalam penelitian audit di pemerintahan. Audit internal yang tidak efektif dalam manajemen sektor publik akan menyebabkan kemungkinan munculnya penipuan, tingkat kepatuhan yang rendah, dan ketidak efektifan dalam pengambilan keputusan keuangan dalam mencapai keberhasilan operasional (Unegbu dan Kida, 2011).

Di Indonesia, penelitian tentang keefektifan audit internal belum banyak dilakukan. Penelitian Putro (2012) menemukan bahwa keefektifan fungsi pengawas Inspektorat di Salatiga dipengaruhi oleh kualitas pengawas, dukungan manajemen, kecukupan sumberdaya manusia dan dana operasional yang memadai. Suyono dan Hariyanto (2012) 
menguji hubungan antara sistem pengendalian intern, audit internal dan komitmen organisasi dengan good governance di kecamatan Provinsi Jawa Tengah. Hasilnya sistem pengendalian intern, audit internal dan komitmen organisasi berhubungan positif terhadap good governance. Mereka menyimpulkan bahwa ketika sistem pengendalian intern itu dan audit internal efektif, komitmen organisasi tinggi maka akan menaikkan praktik good governance.

Albercht et al. (1988) seperti dikutip oleh Karagiorgos, et al. (2011) menyatakan bahwa ada empat faktor yang berpengaruh terhadap keefektifan audit internal yaitu lingkungan perusahaan yang tepat, dukungan manajemen, kualitas staf audit internal dan kualitas kerja audit internal. Dukungan manajemen dalam hal ini pemimpin daerah merupakan salah satu penentu keefektifan audit internal (Cohen dan Sayag, 2010; Endaya dan Hanefah, 2013; Mihret dan Yilmaz, 2007; Van Gansberghe, 2005). Komitmen manajemen untuk mengimplementasikan rekomendasi hasil audit internal merupakan salah satu contoh dukungan terhadap audit internal. Selain itu, suatu sistem tidak akan berjalan dengan baik seandainya komitmen top manajemen dalam hal ini pemimpin daerah kurang.

Faktor lain yang telah terbukti secara empiris berpengaruh terhadap keefektifan audit yaituaudit professionalism (Intakhan dan Ussahawanitchakit, 2010; Ussahawanitchakit, 2011). Audit professionalism merupakan penggerak utama dari keefektifan, kinerja dan kesuksesan audit. Memahami sistem pengendalian intern, dukungan manajemen dan audit professionalism yang berpengaruh terhadap keefektifan audit internal dapat menjelaskan fenomena banyaknya laporan keuangan pemerintah yang belum mendapatkan opini wajar tanpa pengecualian dari BPK.

Hasil penelitian ini diharapkan akan memberikan kontribusi dengan memperkaya litertur terkait dengan keefektifan audit internal di sektor publik melalui pengujian faktorfaktor yang berpengaruh terhadap keefektifan audit internal dan penguatan terhadap sistem pengendalian intern dan audit internal.

\section{KAJIAN TEORI}

Teori Institusional. Ide pokok teori institusional adalah bahwa organisasi dibentuk oleh lingkungan institusional yang mengitarinya dan dengan begitu pengamatan atas organisasi harus dilihat sebagai sebuah totalitas simbol, bahasa, ataupun ritual-ritual yang melingkupinya (Gudono, 2012:167). Menurut DiMaggio dan Powel (1983) organisasi dibentuk oleh kekuatan-kekuatan di luar dirinya melalui proses peniruan dan ketaatan. Konsep yang dikemukakan oleh DiMaggio dan Powel ini dikenal dengan institutional isomorphism.

Konsep isomorphism merupakan proses menjadi sama bentuk; iso artinya sama dan morp artinya bentuk. Isomorphism adalah "constraining process” yang memaksa satu unit didalam populasi untuk memiliki wujud dan sifat yang sama dengan unit yang lain yang menghadapi kondisi lingkungan yang sama (DiMaggio dan Powel, 1983). Hal ini terjadi karena ada dua macam isomorphism yaitu isomorphism kompetitif dan isomorpisme institusional. Menurut Gudono (2012:192) dua macam isomorphism terjadi karena organisasi tidak sekedar bersaing mendapatkan sumberdaya tetapi juga mendapatkan legitimasi institusional atau pun politis.

DiMaggio dan Powel (1983) menjelaskan bahwa konsep isomorphism terdiri dari 3 yaitu coercive, mimetic dan normative yang mempengaruhi struktur dan praktik 
organisasi. Mekanisme isomorpisme coercive merujuk pada proses di mana organisasi mengadopsi fitur (sifat) tertentu karena paksaan dari negara, organisasi lain atau masyarakat (Gudono, 2012: 193). Isomorpisme coercive terjadi karena organisasi berupaya mendapatkan legitimasi.

Mekanisme isomorpisme mimetic terjadi karena organisasi meniru organisasi lain akibat dari ketidakpastian. Dalam situasi ketidakpastian bagaimana memproses sesuatu atau beroperasi, organisasi mungkin akan melakukan proses pembelajaran dengan cara melakukan "benchmarking" atau studi banding atau memakai jasa konsultan (Gudono, 2012). Isomorfisme normatif muncul ketika perubahan institusional terjadi karena pengakuan organisasiprofesi. Dalam konteks penelitian ini audit internal dibentuk oleh pengaruh negara dan profesi.

Teori institusional dapat diterapkan pada unit analisis yang berbeda seperti di level organisasi individu, industri dan yang lainnya (Barley dan Tolbert, 1997 dalam Arena dan Azzone, 2009). Selanjutnya Arena dan Azzone (2009) menjelaskan bahwa teori ini sesuai dengan penelitian di bidang audit internal sebab dapat menjelaskan fenomena organisasi tanpa harus membatasi ruang untuk organisasi "profit seeking". Teori ini juga dapat diterapkan di latar belakang yang berbeda yaitu negara berkembang (Al-Twaijry et al. 2003) dan negara maju ( Arena et al. 2006).

Beberapa penelitian efektivitas audit internal menggunakan teori institusional seperti Al-Twaijry et al. (2003), Arena et al. (2006), Endaya dan Hanefa (2013) dan Mihret et al. (2010) menunjukkan bahwa tingkat efektivitas audit internal tergantung dari negara dan pengaturan audit internal secara umum di organisasi. Swinkels (2012) juga menggunakan teori institusional untuk menjelaskan hubungan antara audit internal dengan sistem pengendalian di perusahaan Belanda.

Teori kelembagaan memiliki beberapa implikasi yang berkaitan dengan kemungkinan konteks ketergantungan efektivitas audit internal. Misalnya, dalam organisasi yang mempunyai risiko tinggi, mungkin berharap tekanan mimetic untuk berkontribusi pada pengembangan audit internal. Oleh karena itu, organisasi sebagai bagian dari upaya mereka untuk mengelola risiko, dapat membentuk departemen audit internal dengan meniru praktek dari organisasi lain. Ini menunjukkan hubungan positif antara tingkat eksposur risiko dari suatu organisasi dan efektifitas audit internal (Goodwin et al. 2004).

Demikian juga, fokus audit internal sebagai jaminan atau konsultasi mungkin berbeda antara pemerintah dan sektor organisasi swasta (Carcelloetal. 2005). Selanjutnya profesionalisasi (dari profesi akuntansi) dapat mengerahkan berbagai tingkat berdampak pada kemajuan atau sebaliknya dari audit internal diseluruh institusi (Al-Twaijry et.al, 2003,2004; Yee et, al. 2008).

Sistem Pengendalian Intern. Pengendalian intern menurut COSO (Committee of Sponsoring Organizations of the treadway Commissions) adalah suatu proses yang dipengaruhi oleh dewan direksi, manajemen dan personil lain dari suatu entitas, yang dirancang untuk memberikan keyakinan yang memadai mengenai pencapaian sasaran dalam keefektifan dan keefesienan operasi, keandalan pelaporan keuangan, dan kepatuhan terhadap hukum dan peraturan yang berlaku.

Menurut COSO pihak pihak yang bertanggung jawab terhadap sistem pengendalian intern adalah semua orang seperti dewan direksi, manajemen, komite audit, auditor internal dan personel lainnya. Dapat ditarik kesimpulan bahwa apabila salah satu pihak 
tidak menjalankan perannya maka sistem pengendalian intern tidak akan berjalan dengan baik. Pihak ketiga seperti auditor eksternal sering memberikan evaluasi dan berkontribusi terhadap pencapaian tujuan organisasi, tetapi auditor eksternal tidak bertanggung jawab terhadap sistem pengendalian intern karena bukan bagian dari sistem pengendalian intern.

Sistem pengendalian intern dalam pemerintah disebut sistem pengendalian intern pemerintah (SPIP). Menurut PP No 60 Tahun 2008 SPIP adalah proses yang integral pada kegiatan dan tindakan yang dilakukan secara terus menerus oleh pimpinan dan seluruh pegawai untuk memberikan keyakinan memadai atas tercapainya tujuan organisasi, melalui kegiatan yang efektif dan efisien, keandalan pelaporan keuangan, pengamanan asset Negara, serta ketaatan terhadap peraturan perundang-undangan. Pemerintah Indonesia mengadopsi SPI yang dikembangkan oleh COSO, adopsi ini dilatarbelakangi tuntutan UU keuangan negara yang membebankan seluruh tingkatan pimpinan menyelenggarakan kegiatan pengendalian intern. SPIP mencoba meninggalkan pemahaman sistem pengendalian intern yang semula hanya berbasis accounting control dan administrative control yang kemudian dipadukan dengan unsur lingkungan pengendalian. SPIP terdiri dari lima unsur yaitu: (1) Lingkungan pengendalian; (2) Penilaian risiko; (3) Kegiatan pengendalian; (4) Informasi dan komunikasi; (5) Pemantauan pengendalian intern

Dukungan Manajemen. Dukungan top manajemen dalam suatu sistem sangatlah penting. Menurut Fernandez dan Rainey (2006) dukungan manajemen dan komitmen untuk berubah memainkan peran penting dalam organisasi. Implementasi suatu sistem menuntut adanya komitmen dan peran aktif pemimpin atau top manajemen. Dalam konteks penelitian ini seperti yang diungkapkan oleh Sawyer (1995) dalam Mihret dan Yilmaz (2007) komitmen manajemen untuk melaksanakan rekomendasi audit dan dukungan penguatan audit internal sangat penting untuk keefektifan audit internal.

Penelitian terdahulu telah membuktikan bahwa dukungan manajemen merupakan salah satu faktor penting dalam keefektifan audit internal (Van Gansberghe, 2005; Mihret dan Yilmaz, 2007; Cohen dan Sayag, 2010 dan Aikins, 2012). Mihret dan Yilmaz (2007) menemukan rekomendasi audit tidak dilaksanakan oleh manajemen, sehingga berpengaruh terhadap keefektifan audit internal. Menurut Cohen dan sayag (2010) dukungan manajemen tidak hanya pada pelaksanaan rekomendasi audit, tetapi juga pada pendanaan, pelatihan dan dukungan terhadap pelaksanaan audit contohnya menyewa tenaga ahli dari luar.

\section{Audit Professionalism}

Audit professionalism merupakan penentu utama dari keefektifan audit (Ussahawanitchakit, 2012) dimana auditor yang mempunyai profesionalisme yang tinggi akan bekerja dengan baik, aktivitas dan tanggung jawab dijalankan dengan baik untuk meningkatkan efisiensi audit dan mendapatkan keefektifan audit. Professionalisma audit berkaitan dengan pekerjaan yang menuntut keahlian yang luar biasa, motivasi dan usaha (Ussahanitchakit, 2012). Audit membutuhkan staf professional yang secara kolektif memiliki pendidikan, pelatihan, pengalaman dan kualifikasi professional untuk melakukan berbagai macam audit yang dibutuhkan oleh tugasnya (Al-Twaijry et al. 2003). Kemampuan professional dari staf instansi audit internal dan manajemen yang baik merupakan kunci untuk operasi yang efektif dari audit internal (Cohen dan Sayag, 2010).

Picket, (2000) seperti dikutip oleh Arena dan Azone (2010) menyatakan bahwa keahlian auditor internal dapat dibedakan menjadi 2 yaitu cognitive dan behavioural skills. 
Cognitive skills sering disebut kompetensi teknis. Ketrampilan teknis akan memastikan auditor menyediakan saran untuk memperbaiki sistem pengendalian intern, memberikan audit yang komplit, menemukan solusi yang konsisten berdasarkan pengalaman sebelumnya. Behavioural skills termasuk komunikasi dan kemampuan berhubungan dengan orang lain. Behavioural skills diperlukan oleh auditor untuk membangun hubungan yang sehat dengan auditee mereka, interpersonal dan kemampuan komunikasi memfasilitasi pemahaman dari temuan audit dan kemampuan untuk mencapai tanggung jawab mereka secara efektif (Arena dan Azone, 2010).

Keefektifan Audit Internal. Lembaga auditor internal (2004) mendefinisikan audit internal sebagai kegiatan independen yang bertujuanmenyediakanjaminan dan konsultasi yang dirancang untuk meningkatkan dan memperbaiki nilai tambah untuk operasi organisasi. Organisasi yang mempunyai audit internal lebih cenderung melaporkan/menemukan kecurangan dan penipuan (Coram et al. 2008; Salameh et al. 2011).

Auditor internal dianggap penting dalam mencegah dan mendeteksi adanya kecurangan dan penipuan. Xiandong (1997) menyatakan bahwa audit internal memiliki keuntungan lebih daripada audit eksternal yaitu dapat memperoleh informasi secara cepat dan menemukan masalah dalam tahap awal. Penelitian Salameh et al. (2011) menemukan bahwa keefektifan audit internal yang dirasakan oleh manajer senior dapat mencegah kecurangan yang terjadi di Bank. Pemahaman terhadap faktor- faktor yang mempengaruhi keefektifan audit internal itu penting karena keefektifan audit internal dapat meningkatkan empat proses penting dalam organisasi yaitu mengajarkan pada anggota organisasi bagaimana melakukan pekerjaan dengan baik (learning), meningkatkan kinerja dengan memperbaiki kelemahan-kelemahan yang ada (motivation), mencegah penyalahgunaan (deterrence) dan audit internaldapat meningkatkan kemungkinanbahwahal yang benardilakukandandilakukan dengan benar (process improvements) (Eden dan Moriah, 1996 dalam Cohen dan Sayag, 2010).

Menurut Arena dan Ozzone (2009) keefektifan memiliki arti kemampuan untuk memperoleh hasil yang konsisten dengan tujuan dan target. Dalam konteks yang sama, suatu program dapat dilihat efektif jika hasilnya sama dengan tujuannya (Mihret dan Yismaw, 2007). Dalam konteks penelitian ini keefektifan audit internal adalah kemampuan auditor untuk mencapai tujuan dari pemerintah daerah (Badara dan Saidin, 2013). keefektifan audit internal telah teruji secara empiris dapat meningkatkan kinerja keuangan organisasi tersebut (Aikins, 2011; Mihret et al. 2010).

Sistem Pengendalian Intern dan Keefektifan Audit Internal. Arena dan Azone (2009) menyatakan bahwa lingkungan organisasi (konteks regulasi dan level dari risiko organisasi) berpengaruh terhadap keefektifan audit internal. Selanjutnya Arena dan Azone (2009) menjelaskan bahwa peran dari hukum dan regulasi mempunyai hubungan dengan keefektifan audit melalui dua cara yang pertama, hukum dan regulasi menentukan aktivitas audit. Khususnya pengaturan dimana perhatian antara pengendalian internal dan audit internal adalah pendekatan organisasi yang diterima tidak hanya berdasarkan pada konsolidasi rutin dan reaksi atau tindakan mereka akan lebih kuat dipengaruhi oleh tekanan luar dalam proses conformance eksternal ( Arenaet al. 2006; DiMaggio dan Powell, 1983). Yang kedua, banyak kasus auditor internal bertindak sebagai translator dari kerangka kerja regulasi. Oleh karena itu membutuhkan kepatuhan terhadap regulasi 
yang spesifik yang berdampak secara tidak langsung persepsi manajer dari kerja internal audit. Dalam konteks penelitian ini sistem pengendalian intern pemerintah (SPIP) merupakan salah satu produk regulasi yang harus diterapkan (isomorpisme coercive) oleh setiap instansi pemerintahan.

Badara dan Saidin (2013) berargumen bahwa menyediakan pengendalian lingkungan yang tepat untuk pemerintah daerah sangat penting untuk keefektifan operasi mereka. Lingkungan pengendalian yang baik akan berpengaruh terhadap organisasi dalam hal ini pemerintah dan begitu pula sebaliknya. Lingkungan pengendalian ini merupakan pondasi yang mendasari suatu sistem pengendalian intern pemerintah. dengan terciptanya lingkungan pengendalian yang baik di pemerintah akan berpengaruh terhadap keefektifan audit internal.

Identifikasi dan analisis dari risiko yang relevant terkait dengan pencapaian tujuan manajemen (Karagiorgos et al. 2011). Dengan adanya penilaian risiko maka setiap entitas akan mengantisipasi faktor-faktor atau hal apa saja yang dapat menghambat tercapainya tujuan organisasi. Sistem pengendalian intern dikatakan efektif apabila komponen komponen itu ada dan berfungsi dengan baik. Penelitian Karagiorgos et al. (2011) memberikan bukti empiris di sektor perhotelan di Yunani bahwa sistem pengendalian intern merupakan faktor penting dari keefektifan audit internal.

Keefektifan sistem pengendalian intern perusahaan diakui sebagai prasyarat untuk proses audit karena dianggap penentu utama pemilihan, waktu dan sejauhmana prosedur audit harus diterapkan atau dibatasi (Terell, 1974 dalam Sawalqa dan Qtish, 2012). Tentunya keefektifan sistem pengendalian intern akan berdampak pada keefektifan audit internal. Auditor internal dalam mengevaluasi sistem pengendalian internal berpedoman pada regulasi yaitu PP No 60 Tahun 2008. Jika komponen-komponen dalam sistem pengendalian intern itu berfungsi dengan baik, maka akan berdampak pada proses audit dan keefektifan audit. Ketika sistem pengendalian intern itu kuat akan menghasilkan dokumen-dokumen transaksi yang lengkap sehingga akan memudahkan auditor internal melakukan prosedur audit. Sistem pengendalian intern yang baik akan menyediakan informasi yang akurat bagi auditor untuk mencapai tujuan organisasi.

H1: Efektivitas sistem pengendalian intern berpengaruh positif pada keefektifan audit internal

Dukungan Manajemen dan Keefektifan Audit Internal. Pelaksanaan sistem pengendalian intern di Indonesia diatur di pasal 313 permendagri No 13 tahun 2006 yang menyatakan bahwa dalam rangka meningkatkan kinerja, transparasi dan akuntabilitas pengelolaan keuangan daerah, kepala daerah mengatur dan menyelenggarakan sistem pengendalian intern dilingkungan daerah yang dipimpinnya. Hal ini jelas tersirat bahwa dukungan top manajemen terhadap sistem pengendalian intern merupakan hal yang krusial tercapainya akuntabilitas laporan keuangan. Sistem pengendalian intern yang sepenuhnya didukung oleh manajemen akan berpengaruh terhadap keefektifan audit internal.

Dukungan manajemen terhadap keefektifan audit internal terlah terbukti secara empiris (Mihret dan Yilmaz, 2007; Cohen dan Sayag, 2010). Menurut Sawyer dalam Cohen dan Sayag (2010) menyatakan bahwa dukungan manajemen untuk fungsi audit internal merupakan faktor sukses dari fungsi audit internal tersebut. Tanpa dukungan dari manajemen maka keefektifan audit internal tidak akan tercapai.

Dukungan manajemen merupakan legitimasi bagi auditor internal. Salah satu bentuk dukungan manajemen yaitu rekomendasi audit internal benar-benar dilaksanakan 
oleh manajemen. Apabila rekomendasi itu tidak dilaksanakan dengan baik, maka berpengaruh pada ketidakefektifan audit internal. Al-Twaijry et al. (2003) menemukan bahwa rekomendasi audit internal terkadang tidak di implementasikan atau dilaksanakan oleh pihak manajemen. Dalam konteks pemerintahan, peran pengawasan programprogram pemerintah tidak hanya terletak pada lembaga yang secara formal mempunyai kewenangan dalam pengawasan seperti inspektorat, BPKP, BPK tetapi juga merupakan tanggung jawab pemimpin daerah atau top manajemen dalam melaksanakan sistem pengendalian yang berdampak pada keefektifan audit. Salah satu tujuan pemerintah yaitu menggunakan anggaran secara efesien dan efektif. Auditor internal yang telah melaksanakan audit, akan memberikan rekomendasi kepada manajemen berdasarkan temuannya. Rekomendasi tersebut diharapkan ditindaklanjuti oleh manajemen agar penggunaan anggaran sesuai dengan tujuannya, apabila rekomendasi tersebut tidak ditindaklanjuti oleh manajemen, maka keefektifan audit internal tidak akan tercapai. Dari hasil temuan audit, auditor akan menyarankan perbaikan bagi manajemen, dukungan top manajemen atau komitmen manajemen untuk melakukan saran dari auditor akan membuat auditor yakin terhadap audit yang dilakukan dan akan memperbaiki kelemahankelemahan dalam organisasi. Hal ini akan berdampak pada hasil audit yang sesuai dengan tujuan organisasi.

H2: Dukungan manajemen berpengaruh positif terhadap keefektifan audit internal

Audit Professionalism dan Keefektifan Audit Internal. Audit professionalism menuntut auditor untuk mengerahkan pengetahuan, penilaian, kompetensi dan kemampuan melalui pelaporan aktivitas audit yang berharga (Intakhan, 2010). Penggunaan kemahiran professional dengan cermat dan seksama merupakan pertimbangan sehat dalam lingkup, pemilihan metodologi, dalam pengujian dan prosedur untuk mengaudit. Auditor dituntut untuk memiliki objectivity, komunikasi yang efektif, keahlian, due professional care, pengembangan dan pelatihan yang dapat meningkatkan keefektifan audit internal (Khaled dan Endaya, 2013).

Auditor internal harus memiliki pengetahuan, ketrampilan dan kompetensi lainnya yang dibutuhkan untuk mencapai tanggung jawab mereka (proficiency dan due professional care) dan auditor internal harus selalu mengikuti program pengembangan dan pelatihan untuk berperilaku professional. Penilaian professional akan kehilangan nilai apabila ada keraguan objectivity dari auditor internal. Temuan dari auditor internal akan tidak bermakna apabila auditor internal tidak mempunyai kemampuan berkomunikasi yang efektif, sehingga auditor internal dituntut untuk memiliki kemampuan berkomunikasi.

H3: Audit professionalism berpengaruh positif pada keefektifan audit internal

\section{METODE}

Sampel. Sampel dalam penelitian ini adalah Inspektorat Daerah kota/kabupaten. Teknik pengambilan sampel menggunakan metode non probabilistic sampling yaitu setiap elemen dalam populasi tidak memiliki probabilitas yang sama untuk menjadi sampel (Sekaran, 2003). Teknik penentuan sampel secara non probabilitas dalam penelitian ini adalah snowball sampling yaitu pengambilan sampel yang dilakukan dengan mengumpulkan sampel dari responden yang berasal dari referensi suatu jaringan (Hartono, 2011). Daerah yang dipilih untuk menjadi objek penelitian ini yaitu Inspektorat kabupaten/kota Propinsi 
DIY, Inspektorat kabupaten/kota Propinsi Bangka Belitung, Inspektorat kabupaten/kota Propinsi Jawa Barat, Inspektorat kabupaten/kota Propinsi Jawa Tengah, Inspektorat kabupaten/kota Propinsi Jambi, dan Inspektorat kabupaten/kota propinsi Maluku.

Teknik pengumpulan data dalam penelitian ini berupa survey. Jenis survey yang digunakan adalah survey online, pos dan antar langsung Sebelum kuisioner di sebarkan, peneliti terlebih dahulu menghubungi pihak Inspektorat Daerah dengan menjelaskan tujuan utama penelitian dan permohonan bantuan. Setelah mendapatkan jawaban dari humas inspektorat daerah, maka peneliti mengirimkan link kuisioner online tersebut ke alamat email yang tercantum pada web inspektorat daerah. Untuk mendapatkan informan yang sesuai dengan kriteria penelitian, peneliti menjelaskan kepada humas inspektorat daerah tersebut bahwa yang mengisi kusioner ini paling tidak memiliki golongan 3B atau pernah menjadi ketua/pengawas audit.

Definisi operasional dan pengukuran variabel. Sistem Pengendalian Intern. Sistem pengendalian intern didefinisikan sebagai proses yang integral pada kegiatan dan tindakan yang dilakukan secara terus menerus oleh pimpinan dan seluruh pegawai untuk memberikan keyakinan memadai atas tercapainya tujuan organisasi, melalui kegiatan yang efektif dan efisien, keandalan pelaporan keuangan, pengamanan asset negara, serta ketaatan terhadap peraturan perundang-undangan.Variabel ini diukur dengan instrumen yang dikembangkan oleh COSO (1999). Instrumen ini terdiri dari 10 item pertanyaan item dengan 5 faktor yaitu lingkungan pengendalian, penilaian risiko, kegiatan pengendalian,informasi dan komunikasi, pemantauan pengendalian intern. Responden diminta untuk menunjukkan tingkat persetujuannya dengan memilih angka 1 (sangat tidak setuju) sampai 5 (sangat setuju). Seluruh item pertanyaan dalam penelitian ini diacak untuk mencegah responden memahami beberapa item mengarah ke konstruk yang sama sehingga responden akan menjawab dengan monoton di nilai-nilai bawah saja (floor effect) atau diatas saja atau Ceiling effect (Hartono, 2011).

Dukungan Manajemen. Dukungan manajemen didefinisikan sebagai dukungan dan komitmen manajemen untuk mengimplementasikan rekomendasi dari temuan audit (Mihret dan Yilmaw, 2007). Variabel ini diukur dengan 3 item yang diadopsi dari Coper et al. (1996). Responden diminta untuk menunjukkan tingkat persetujuannya dengan memilih angka 1 (sangat tidak setuju) sampai 5 (sangat setuju).

Audit Professionalism. Audit Professionalism didefinisikan sebagai "preference by auditors to exercise individual professional judgement in auditing tasks" (Askary, 2006). Variabel ini diukur dengan 2 item yang telah digunakan oleh Cohen dan Sayag (2010). Responden diminta untuk menunjukkantingkat persetujuannya dengan memilih angka 1 (sangat tidak setuju) sampai 5 (sangat setuju).

Keefektifan Audit Internal

Keefektifan audit internal didefinisikan sebagai "the capacity to obtain results that are consistent with targets objective”(Arena and Azone, 2009). Variabel ini diukur dengan pertanyaan yang dikembangkan oleh Cohen dan Sayag (2010). Pertanyaan terdiri dari 35 item dengan tiga faktor yaitu faktor audit quality, auditees evaluations, dan added contribution of internal audit.Responden diminta untuk menunjukkan tingkat persetujuannya dengan memilih angka 1 (sangat tidak setuju) sampai 5 (sangat setuju). 


\section{Uji Validitas}

Tabel 3. Hasil analisis factor

\begin{tabular}{|c|c|c|c|c|}
\hline $\begin{array}{l}\text { Nomor } \\
\text { Pertanyaan }\end{array}$ & $\begin{array}{l}\text { Sistem } \\
\text { Pengendalian } \\
\text { Internal }\end{array}$ & $\begin{array}{l}\text { Dukungan } \\
\text { Manajemen }\end{array}$ & $\begin{array}{l}\text { Audit } \\
\text { Profesionalisme }\end{array}$ & $\begin{array}{l}\text { Keefektifan } \\
\text { audit internal }\end{array}$ \\
\hline Item 1 & 0,812 & 0,769 & 0,897 & 0,601 \\
\hline Item 2 & 0,906 & 0,859 & 0,897 & 0,594 \\
\hline Item 3 & 0,869 & 0,565 & & 0,579 \\
\hline Item 4 & 0,775 & & & 0,574 \\
\hline Item 5 & 0,801 & & & 0,510 \\
\hline Item 6 & 0,840 & & & 0,694 \\
\hline Item 7 & 0,819 & & & 0,539 \\
\hline Item 8 & 0,664 & & & 0,777 \\
\hline Item 9 & 0,630 & & & 0,695 \\
\hline Item 10 & 0,878 & & & 0,710 \\
\hline Item 11 & & & & 0,646 \\
\hline Item 12 & & & & 0,770 \\
\hline Item 13 & & & & 0,761 \\
\hline Item 14 & & & & 0,695 \\
\hline Item 15 & & & & 0,690 \\
\hline Item 16 & & & & 0,594 \\
\hline Item 17 & & & & 0,610 \\
\hline Item 18 & & & & 0,523 \\
\hline Item 19 & & & & 0,716 \\
\hline Item 20 & & & & 0,767 \\
\hline Item 21 & & & & 0,664 \\
\hline Item 22 & & & & 0,389 \\
\hline Item 23 & & & & 0,774 \\
\hline Item 24 & & & & 0,623 \\
\hline Item 25 & & & & 0,160 \\
\hline Item 26 & & & & 0,264 \\
\hline Item 27 & & & & 0,164 \\
\hline Item 28 & & & & 0,724 \\
\hline Item 29 & & & & 0,346 \\
\hline Item 30 & & & &,- 091 \\
\hline Item 31 & & & & 0,641 \\
\hline Item 32 & & & & 0,657 \\
\hline Item 33 & & & & 0,659 \\
\hline Item 34 & & & & 0,590 \\
\hline Item 35 & & & & 0,123 \\
\hline
\end{tabular}

Uji validitas digunakan untuk menguji apakah item kuisioner benar-benar menguji konsep yang dimaksudkan dengan tepat. Uji validitas dilakukan dengan perhitungan analisis faktor terhadap item-item kuisioner. Hasil uji faktor analisis dapat dikatakan valid sebagai instrument penelitian apabila loading factor berada di atas 0.40 dan eigenvalues lebih dari 1 (Hair et al., 2010). Variabel sistem pengendalian intern menggunakan 10 item pertanyaan sebagai alat ukurnya dan seluruh item pertanyaan memenuhi persyaratan factor loading di atas 0,5. Variabel dukungan manajemen dan audit professionalism juga memenuhi persyaratan factor loading diatas 0,5. Sedangkan variabel keefektifan audit internal menggunakan 35 pertanyaan yang sebagai alat ukurnya. Hasil analisis faktor 
menunjukkan bahwa ada beberapa pertanyaan yang tidak memenuhi syarat factor loading yaitu pertanyaan 22, 25, 26, 27,29, 30, dan 35 dengan nilai sebesar 0,389, 0,160, 0,264, 0,164, 0,346, -,091, dan 0,123. Pertanyaan yang tidak memenuhi syarat factor loading dieliminasi dan yang digunakan untuk analisis selanjutnya hanya item pertanyaan yang memenuhi syarat factor loading.

Uji Reliabilitas. Uji reliabilitas digunakan untuk mengetahui tingkat kestabilan dan konsistensi alat ukur yang digunakan untuk mengukur konsep bias dapat diminimalkan (Sekaran, 2003). Pengukuran reliabilitas dalam penelitian ini lebih mengedepankan internal consistency suatu kuisioner. Pada penelitian ini pengukuran item consistency suatu kuisioner dengan merujuk pada nilai cronbach alpha.

Uji reliabilitas dilakukan dengan menggunakan tingkat pengukuran koefisien Cronbach's Alpha.Koefisien Cronbach's Alpha merupakan koefisien reliabilitas yang menunjukkan seberapa baik item dalam penelitian saling berkorelasi positif antara satu dengan yang lain (Sekaran, 2003).Uji reliabilitas berkaitan dengan akurasi dan presisi dari sebuah prosedur pengukuran (Cooper dan Schindler, 2011:283). Suatu kuisioner dikatakan reliable jika jawaban seseorang terhadap pernyataan adalah kosisten, atau stabil dari waktu ke waktu dan nilai cronbach alpha > 0,60 (Nunally, 1994 dalam Ghozali, 2011:51).

Tabel 4. Hasil Pengujian Cronbach Alpha

\begin{tabular}{llll}
\hline \multicolumn{1}{c}{ Variabel } & & Jumlah Item & Cronbach's Alpha \\
\hline Sistem Pengendalian Intern & 10 & 0,788 \\
Dukungan Manajemen & 3 & 0,556 \\
Audit profesionalism & 2 & 0,758 \\
Keefektifan audit internal & 28 & 0,794 \\
\hline
\end{tabular}

Tabel 4 menunjukkan bahwa variabel sistem pengendalian intern audit professionalism dan keefektifan audit internal memiliki nilai cronbach alpha di atas 0,6 sehingga dapat dikatakan variabel tersebut memiliki reliabilitas yang baik. Untuk variabel dukungan manajemen, nilai koefisien alpha berada di bawah 0,6 hal ini menunjukkan bahwa instrument ini dianggap kurang baik. Hal ini berarti pengukuran yang digunakan kurang akurat dan konsisten.

\section{HASIL DAN PEMBAHASAN}

Tabel 2. Statistik Deskriptif

\begin{tabular}{llllll}
\hline Variabel & N & $\begin{array}{l}\text { Nilai } \\
\text { Minimum }\end{array}$ & $\begin{array}{l}\text { Nilai } \\
\text { Maximum }\end{array}$ & Rata- rata & $\begin{array}{l}\text { Deviasi } \\
\text { Standar }\end{array}$ \\
\hline Sistem pengendalian Intern & 39 & 3,09 & 4,89 & 3,81 & 0,363 \\
Dukungan Manajemen & 39 & 3.00 & 5,00 & 3,87 & 0,741 \\
Audit Profesionalism & 39 & 2,67 & 5,00 & 3,66 & 0,501 \\
Keefektifan Audit Internal & 39 & 2,00 & 5,00 & 3,76 & 0,724 \\
\hline
\end{tabular}

Berdasarkan statistik deskriptif di atas, variabel sistem pengendalian Intern mempunyai nilai minimum 3,09 dan nilai maximum 4,89. Nilai rata-rata variabel ini 3,81 
dengan standar deviasi 0,363. Variabel dukungan manajemen mempunyai nilai minimum 3,00, nilai Maximum 5,00 rata-rata 3,87 dengan standar deviasi 0,741. Variabel Audit Profesionalism mempunyai nilai minimum 2,67, nilai Maximum 5,00. Nilai rata-rata variabelaudit professionalism 3,66 dengan standar deviasi 0,501. Variabel Keefektifan audit internal mempunyai nilai minimum 2,00, nilai Maximum 5,00, rata-rata 3,76 dengan standar deviasi 0,724.

Uji F

Hasil analisis menunjukkan bahwa goodness of fit model cukup memadai dengan $F$ value sebesar 88,15, dan signifikan pada tingkat alpha sebesar 0,000. Nilai koefisien determinasi atau $R$ square untuk model ini adalah 0,43 artinya bahwa 43\% variasi variabel keefektifan audit internal dijelaskan oleh oleh ketiga variabel independennya yaitu sistem pengendalian intern, dukungan manajemen dan audit professionalism. Uji F-test menunjukkan bahwa, model regresi dapat digunakan untuk memprediksi keefektifan audit internal.

\section{Uji t}

Tabel 5. Hasil Analisis Regresi Faktor-Faktor yang Mempengaruhi Keefektifan Audit Internal

\begin{tabular}{lcccc}
\hline \multicolumn{1}{c}{ Variabel } & Koefisien & Std. Error & t-hitung & $\begin{array}{c}\text { p.value } \\
\text { (signifikansi) }\end{array}$ \\
\hline Konstanta & 1,577 & 0,467 & 3,381 & 0,002 \\
SistemPengendalian Intern & 0,309 & 0,104 & 2,967 & 0,005 \\
DukunganManajemen & 0,302 & 0,101 & 2,976 & 0,005 \\
Audit Profesionalism & $-0,016$ & 0,067 & $-0,240$ & 0,812 \\
\hline
\end{tabular}

$\mathrm{N}$ : 39.Pengujian one-tailed test.

Berdasarkan Tabel 5 prediksi hipotesis satu bahwa Sistem pengendalian intern berpengaruh positif terhadap keefektifan audit internal secara empiris didukung. Dengan kata lain $\mathrm{H}_{0}$ yang menyatakan sistem pengendalian intern tidak berpengaruh terhadap keefektifan audit ditolak. Koefisien sistem pengendalian intern dengan nilai thitungsebesar 2,967 atau lebih besar dari nilai t-tabel 1,686. Selain itu nilai probabilitas $p$ value sebesar 0,005 atau signifikan pada 0,05 dengan arah yang sesuai dengan prediksi yaitu positif.

Hipotesis dua menyatakan bahwa dukungan manajemen berpengaruh positif terhadap keefektifan audit internal. Hasil pengujian menunjukkan bahwa variabel dukungan manajemen memiliki nilai t-hitung sebesar 2,976 dan nilai probabilitas $p$-value sebesar 0,005. Nilai t hitung 2,976 lebih besar dari t tabel dan nilai probabilitas 0,005 lebih kecil dari 0,05 serta hasil uji statistic dengan koefisien yang bernilai positif menunjukkan bahwa dukungan manajemen mempengaruhi keefektifan audit internal. Maka $\mathrm{H}_{0}$ yang menyatakan dukungan manajemen tidak berpengaruh terhadap keefektifan audit internal ditolak dan hasil penelitian ini mendukung prediksi $\mathrm{H}_{\mathrm{a}}$, yang menyatakan dukungan manajemen berpengaruh positif terhadap keefektifan audit internal.

Hipotesis tiga menyatakan bahwa audit professionalism berpengaruh positif terhadap keefektifan audit internal. Hasil pengujian menunjukkan bahwa variabel audit professionalism memiliki nilai t hitung sebesar $-0,24$ dengan nilai probabilitas sebesar 0,812. Nilai t hitung ini lebih kecil dari t tabel 1,686 dan nilai probabilitasnya lebih besar dari 0,05, menunjukkan bahwa audit professionalism tidak berpengaruh terhadap 
keefektifan audit. Berdasarkan bukti empiris tersebut, maka penelitian ini gagal menolak $\mathrm{H}_{0}$ yang menyatakan bahwa audit professionalism tidak berpengaruh terhadap keefektifan audit internal.

Pembahasan

Hasil pengujian hipotesis pertama menunjukkan sistem pengendalian intern berpengaruh positif terhadap keefektifan audit internal. Hasil penelitian ini mengkonfirmasi penelitian Arena dan Azzone (2009) yang menemukan bahwa konteks regulasi berpengaruh terhadap keefektifan audit internal. Karagiorgos, et al. (2011) juga menemukan bahwa sistem pengendalian intern berpengaruh terhadap keefektifan audit internal di sector perhotelanYunani. Sistem pengendalian intern merupakan kunci bagi organisasi dari hal hal yang tidak diinginkan tidak terkecuali dari staf/ pegawainya sendiri. Implementasi sistem pengendalian intern yang diatur dalam PP No 60 Tahun 2008 sangat penting, karena tujuan instansi dapat tercapai apabila semua unsure menjalankan sistem pengendalian intern. Dalam peraturan tersebut di jelaskan bahwa Inspektorat Daerah merupakan bagian dari aparat pengawas intern pemerintah, diharapkan dapat memberikan pengawasan secara efektif. Normanton seperti dikutip oleh Radcliffe (2012) menyatakan bahwa audit pemerintah diarahkan pada pemeriksaan berbagai lembaga yang bertujuan untuk akuntabilitas dan penggunaan sumberdaya secara efektif.

Kelima unsur sistem pengendalian intern wajib dilaksanakan oleh semua pegawai Inspektorat terutama pengendalian lingkungan, karena unsur ini akan membentuk budaya dan perilakumanusia. Dengan lingkungan pengendalian yang baik, akan meningkatkan kemampuan untuk menilai risiko yang berdampak pada kegiatan pengendalian. Kegiatan pengendalian terkait dengan kemampuan untuk memilih jenis pengendalian. Semua unsur dalam sistem pengendalian perlu dikomunikasikan dengan baik dan dievaluasi agar sesuai dengan visi Inspektorat daerah yaitu terwujudnya pemerintahan yang baik melalui pengawasan yang professional. Penelitian ini memberikan bukti empiris, dari persepsi auditor internal bahwa implementasi sistem pengendalian intern dapat berpengaruh terhadap keefektifan audit.

Hasil pengujian hipotesis kedua menunjukkan dukungan manajemen berpengaruh positif terhadap keefektifan audit internal. Implementasi rekomendasi audit oleh manajemen merupakan salah satu penguatan untuk fungsi audit internal dan untuk tindakan preventif. Tindakan preventif yaitu mencegah terjadinya kesalahan dalam pelaksanaan program atau kegiatan SKPD. Hasil penelitian ini konsisten dengan penelitian terdahulu yang menemukan bahwa dukungan manajemen berpengaruh terhadap keefektifan audit internal (Van Gasberghe, 2005; Mihret dan Yismaw, 2007; dan Cohen dan sayag, 2010). Dukungan manajemen dapat berupa pengakuan prestasi atau keahlian auditor internal. Pengakuanakan prestasi dari pejabat eselon kepada auditor internal dalam hal ini inspektorat dapat membantu auditor internal dalam menjalankan tugasnya. Praktik audit internal dipengaruhi oleh para pemangku kepentingan, dukungan organisasi untuk audit internal dan status dari sistem pengendalian intern (Sarens, 2010).

Hasil analisis menunjukkan bahwa hipotesis ketiga yang memprediksi bahwa audit professionalism berpengaruh positif terhadap keefektifan audit internal tidak didukung. Tidak terdukungnya hipotesis ini tidak sejalan dengan pendapat Ussahawanitchakit (2012) yang menyatakan bahwa auditor yang mempunyai profesionalisma yang tinggi akan meningkatkan keefektifan audit. Semakin tinggi profesionalisma auditor akan berpengaruh terhadap kualitas audit. Roussy (2013) menemukan bahwa tugas utama auditor internal di sector publik Canada adalah melayani top manajemen dan organisasi, bukan sebagai 
watchdog governance. Selain itu mungkin saja profesionalismea uditor yang ada saat ini lebih kepada kepatuhan dibandingkan penambahan nilai, sehingga tidak mengherankan bahwa audit profesionalisme tidak berpengaruh terhadap keefektifan audit yang terdiri dari tiga dimensi yaitu kualitas audit, penambahan nilai dan evaluasi auditee. Dibutuhkan skill yang spesifik bagi auditor internal sector public dalam memahami tingkat pengendalian dan risiko di sector publik.

Hasil penelitian ini sama dengan penelitian Cohen dan Sayag (2010) di Israel kecakapan professionalisma auditor internal tidak berpengaruh terhadap keefektifan audit internal. Selanjutnya mereka menjelaskan bahwa keefektifan audit internal tergantung pada karakteristik organisasi/manajerial dibandingkan kualifikasi dari staf auditor internal. Penelitian Arena dan Azzone (2009) menemukan bahwa sumberdaya dan kompetensi auditor internal di perusahaan Italia juga tidak berpengaruh terhadap keefektifan audit internal. Kompetensi sebagai proksi dari pengalaman, sertifikasi dan pelatihan terbukti secara empiris tidak berpengaruh terhadap pengungkapan material weakness (Lin, et al. 2011). Hasil penelitian ini berbeda dengan penelitian Nurzanah (2011) yang menemukan bahwa profesionalisma berpengaruh positif terhadap keefektifan pemeriksaan auditor inspektorat kotamadya Metro.

\section{PENUTUP}

Simpulan. Penelitian ini ditujukan untuk menguji pengaruh sistem pengendalian intern, dukungan manajemen dan audit professionalism terhadap keefektifan audit internal. Penelitian dengan metode survey ini menggunakan 94 ketua tim audit dari 39 Inspektorat daerah. Hasil penelitian ini menunjukkan bahwa sistem pengendalian intern, dukungan manajemen berpengaruh positif terhadap keefektifan audit internal. Selain itu dalam penelitian ini gagal menemukan bukti empiris audit professionalism berpengaruh terhadap keefektifan audit internal. Hasil hipotesis di atas dapat disimpulkan bahwa hanya sistem pengendalian intern yang berpengaruh terhadap keefektifan audit internal. Hal ini menunjukkan bahwa sistem pengendalian intern peran kunci dari keefektifan audit internal. Hasil riset ini diharapkan bermanfaat kepada pemerintah daerah mengenai pentingnya implementasi sistem pengendalian intern yang diatur dalam PP No 60 Tahun 2008.

PCAOB seperti dikutip oleh Stefaniak dan Cornell (2011) menyatakan bahwa auditor eksternal akan mempertimbangkan keefektifan departemen audit internal, sebelum mereka bergantung pada penilaian auditor internal ketika menjalankan tugasnya memberikan opini audit. Beberapa penelitian telah membuktikan bahwa auditor eksternal bergantung pada hasil kerja auditor internal dalam menjalankan tugasnya, tetapi auditor eksternal sebelumnya telah mempertimbangkan kualitas dari fungsi audit internal (Schneider, 1985; Aldred, et al. 2013).

Keterbatasan dalam penelitian ini yaitu tingkat responratenya rendah, sehingga harus berhati hati dalam menarik kesimpulan dari penelitian ini. Instrumen untuk mengukur keefektifan audit internal yang dikembangkan oleh Cohen dan Sayag (2010) dalam penelitian ini ada beberapa item yang belum memenuhi syarat validitas untuk mengukur variabel yang seharusnya diukur. Akibatnya kemungkinan besar item-item pertanyaan yang digunakan untuk menguji variabel keefektifan audit internal tidak betul betul mengukur semua yang seharusnya diukur. Penggunaan snowball sampling mempunyai keterbatasan yaitu peneliti memiliki sedikit kontrol karena hanya memilih 
sampel diawal, selanjutnya sampel dipilih orang subyek-subyek yang telah dipilih sebelumnya.

Saran untuk penelitian selanjutnya sebaiknya menambah sampel agar tingkat generalisasinya lebih tinggi. Rendahnya reliabilitas dari instrument variabel dukungan manajemen dapat menjadi motivasi bagi penelitian mendatang untuk mencari instrument pengukur variabel dukungan manajemen dengan menambah atau mencari sumber-sumber lain sehingga mewakili variabel tersebut. Selain itu peneliti selanjutnya dapat mencari instrument pengukur variabel keefektifan audit internal lainnya karena dalam penelitian ini instrument tersebut ada beberapa yang tidak lolos uji validitas.

Tidak terdukungnya hipotesis tiga yang memprediksi audit professionalism berpengaruh positif terhadap keefektifan audit internal dapat menjadi motivasi bagi penelitian selanjutnya untuk meneliti isu tersebut. Peneliti selajutnya dapat menambah variabel moderasi karena ada beberapa penelitian yang menemukan bahwa audit professionalism berpengaruh terhadap keefektifan audit internal (Nurzanah, 2011; Ussahawanitchakit, 2012) dan beberapa penelitian tidak menemukan hubungan signifikan audit professionalism terhadap keefektifan audit internal (Arena dan Azzone, 2009; Cohen dan Sayag, 2010) atau menggunakan metode eksperimen untuk menguji pengaruh audit professionalism terhadap keefektifan audit internal. Arena dan Azzone (2009) menyatakan bahwa peneliti selanjutnya harus mulai dari analisis yang rinci dari kompetensi yang secara teoritis diperlukan oleh auditor internal untuk memahami ketrampilan khusus yang dapat berpengaruh terhadap keefektifan audit internal.

\section{DAFTAR RUJUKAN}

Agindawati, I. (2012) Pengaruh Sistem Pengendalian Intern Pemerintah (SPIP) terhadap Penyataan Opini. Badiklatda.Jabarprov.go.id/index.

Ahmad, N., Othman, R., dan Jusoff, K. (2009) "The Effectiveness of Internal Audit in Malaysian Public Sector”. Journal of Modern Accounting and Auditing: 784-790.

Aikins, S. (2011) An Examination of Government Internal Audits' Role in Improving Financial Performance. Public Finance and Management: 306-337.

Aikins, S. (2012) "Deterimants of Auditee Adoption of Audit Recommendations: Local Government Auditors Perspective”. Journal of Budgeting, Accounting, and Financial Management: 195-220.

Aldred, C.W.B., Brandon, D.M., Messier, W.F., Rittenberg, L.E., dan Stefaniak, C.M. (2013) "A Summary of Research on External Auditor Reliance on the Internal Audit Fuction. Auditing”, A Journal Practice and Theory: Vol 32 Suplmement I.

Allegrini, M., Paape, L., Meville, R., dan Sarens, G. (2006) “The European Literature Review on Internal Auditing”. Managerial Auditing Journal: 845-853.

Al-Twaijry, A.A.M., Brierley, J.A., dan Gwilliam, D.R. (2003) The Development of Internal Audit in Saudi Arabia: an Institutional Theory Perspective. Critical Perspective on Accounting: 507-531.

Al-Twaijry, A.A.M., Brierley, J.A., dan Gwilliam, D.R. (2004) “An Examination of the Relationship between Internal and External Audit in the Saudi Arabian Corporate Sector”. Managerial Auditing Journal: 929-944.

Arena, M., Arnaboldi, M., dan Azzone, G. (2006) "Internal Audit in Italian Organizations: A Multiple Case Study”. Managerial Auditing Journal. 
Arena, M., dan Azzone, G. (2009) "Identifying Organizational Drivers of Internal Audit Effectiveness”. International Journal of Auditing: 43-60.

Askary, S. (2006) "Accounting Professionalism - A Cultural Perspective of Developing Countries”. Managerial Auditing Journal: 102-111.

Badara, M.S., dan Saidin, S.Z. (2013) "Impact of the Effective Internal Control System on the Internal Audit Effectiveness at Local Government Level”. Journal of Social and Development Sciences: 16-23.

Baltaci, M., dan Yilmaz, S. (2006) Keeping an Eye on Subnational Governments: Internal Control and Audit at Local Levels. World Bank Institute.

Cohen, A., dan Sayag, G. (2010) The Effectiveness of Internal Auditing: an Empirical Examination of its Determinants in Israel Organizations. Australian Accounting Review.

Cooper, B.J., Leung, P., dan Mathews, C. (1996) "Benchmarking-a Comparison of Internal Audit in Australia, Malaysia, and Hongkong”. Managerial Auditing Journal: 23-29.

Cooper, D.R., dan Schindler, P.S. (2011) Business Research Method. Singapore: McGraw Hill.

Coram, P., Ferguson, C., dan Moroney, R. (2008) Internal Audit, Alternative Audit Structure and the Level of Misappropriation of Asset Fraud. Accounting and Finance: 543-559.

DiMaggio, P. J., dan Powel, W.W. (1983) The Iron Cage Revisited: Institutional Isomorphism and Collective Rationality in Organizational Fields. American Sociological Review: 147-160.

Endaya, K.A., dan Hanefa, M.M. (2013) "Internal Audit Effectiveness: an Approach Proposition to Develop the Theoretical Framework". Research Journal and Finance and Accounting.

Fernandez, S., dan Rainey, H.G. (2006) Managing Successfull Organizational Change in the Public Sector. Public Administration Review.

Ghozali, I. (2011) Aplikasi Analisis Multivariate dengan Program IBM SPSS 19. Semarang: UNDIP.

Goodwin, J. (2004) “A Comparison of Internal Audit in the Privat and Public Sectors". Managerial Auditing Journal, 19 No. 5: 640-650.

Gudono. (2012) Teori Organisasi. Yogyakarta: BPFE.

Hair, J. (2010) Multivariate Data Analysis - A Global Perspective. New Jersey: Pearson.

Hartono, J. (2011) Pedoman Survei Kuesioner: Pengembangan Kuesioner, Mengatasi Bias dan Meningkatkan Respon. Yogyakarta: BPFE.

Hass, S., Abdolmuhammadi, M.J., dan Burnaby, P. (2006) ”The Americas Literature Review on Internal Auditing”. Managerial Auditing Journal, 21 No. 8: 885-944.

Intakhan, P. d. (2010) "Roles of Audit Experience and Ethical Reasoning in Audit Professionalism and Audit Effectiveness through a Moderator of Stakeholders Pressure: An Empirical Study of Tax Auditors in Thailand”. Journal of Academy of Business and Economics: 10.

Jokipii, A. (2010) "Determinants and Consequences of Interal Control in Firm: a Contingency Theory Based Analysis”. Journal Management Government: 115-144.

Karagiorgos, T., Dragalas, G., dan Giovanis, N. (2011) "Evaluation of the Effectiveness of Internal Audit in Greek Hotel Business”. International Journal of Economic Sciences and Applied Research, 4 (1): 19-34. 
Kidwell, L., dan Lowensohn, S. (2011) "A Review and Assessment of Behavioral Accounting Research in Government”. Journal of Accounting Literature, 30.

Kuta, H. (2008) Effectiveness of Auditing for Proper Accountability in Nigerian Local Governments. Retrieved October 4, 2014, from http://papers.ssrn.com/so13/cf

Lin, S., Pizzini, M., Vargus, M., dan Indranil, M.B. (2011) The Role of Internal Audit Function in The Disclosure Material Weakness. The Accounting Review: 86 No. 1.

Mihret, D.G., dan Yismaw, A.W. (2007) "Internal Audit Effectiveness: An Ethiopian Public Sector Case Study”. Managerial Auditing Journal: 22 No. 5.

Mihret, D.G., James, K., dan Mula, J.M. (2010) Antecedent and Organizational Performance Implication of Internal Audit Effectiveness. Pasific Accounting Review: 22 No. 3.

Nurzanah, E. (n.d.) "Perngaruh Persepsi Auditor Inspektorat Kotamadya Metro tentang Independensi dan Profesionalisma terhadap Efektivitas Pemeriksaan”. Thesis UGM.

Penno, M. (1990) Auditing for Performance Evaluation. The Accounting Review: 65 No. 3.

Prawitt, D.F., Smith, J.L., dan Wood, D.A. (2008) Internal Audit Quality and Earnings Management. Institute of Internal Auditors Research Foundation: 1-42.

Radcliffe, V. (2012) The Election of Auditors in Government: A Study of Politics and The Professional. Accounting and the Public Interest: 12.

Rezaee, Z. (1995) "What the Coso Report Means for Internal Auditors”. Managerial Auditing Journal: 10 No. 6.

Roussy, M. (2013). Internal Auditors' Roles: From Watchdogs to Helpers and Protectors of the Top Manager. Critical Perspective on Accounting: 24, 550-571.

Ryan, C., Trevor, S., dan Morton, N. (2002) Accountablity Disclosure by Quesland Local Government Councils. Financial, Accountability, and Management: 18 No. 3.

Salameh, R., Al-Weshah, G., Al-Nsour, M., dan Al-Hiyari, A. (2011) Alternative Internal Audit Structures and Perceived Effectivenes of Internal Audit in Fraud Prevention. Canadian Social Science: 7 No. 3.

Sarens, G. (2009) The Role of Internal Auditing in Corporate Govenance: Qualitative and Quantitative Insight on the Influence of Organizational Characteristic. Dissertation Universiteit Gent.

Sawalqa, F., dan Qtish, A. (2012) Internal Control and Audit Program Effectiveness: Empirical Evidance from Jordan. International Business Research: 5 No. 9.

Schneider, A. (1985) “The Reliance of External Auditors on Internal Audit Function”. Journal of Accounting Research: 23 No. 2.

Sekaran, U. (2003) Research Methods for Business: Metodologi Penelitian Untuk Bisnis. Jakarta: Salemba Empat.

Spraakman, G. (1997) “Transaction Cost Economics: A Theory for Internal Audit”. Managerial Auditing Journal: 323-330.

Stefaniak, C.M., dan Cornell, R.M. (2011) Social Identification and Difference in External and Internal Auditor Objectivity. American Accounting Association.

Suyono, E., dan Hariyanto, E. (2012) Relationship Control, Internal Audit, and Organization Commitment with Good Governance: Indonesia Case. China-USA Business Review: 11 No. 9.

Swinkels, W. (2012) Exploration of a Theory of Internal Audit: A Study on the Foundations of Internal Audit in Relation to the Nature and the Control System of Dutch Public Listed Firms. Desertasi Van Amsterdam University. 
Unegbu, A.O., dan Kida, M. (2011) "Effectiveness of Internal Audit as Instrument of Improving Sector Management”. Journal of Emerging Trends in Economics and Management Science: 304-309.

Ussahawanitchakit, P. (2012) "Ethical Orientation, Ethical Reasoning, Professional Commitment, Audit Professionalism, and Audit Effectiveness of CPAs in Thailand". Journal of International Business and Economics.

Van der Stede, W.A., Young, S.M., dan Chen, C.X. (2005) Assessing the Quality of Evidence in Empirical Management Accounting Research: The Case of Survey Studies. Accounting, Organization, Society: 30, 655-684.

Van Gasberghe, C. (2005) "Internal Auditing in the Public Setor: A Consultative Forum in Nairobi, Kenya, Shores up Best Practices for Government Audit Professional in Developing Nations". Internal Auditor: 69-73.

Vijayakumar, A.N., dan Nagaraja, N. (2012) Internal Control Systems: Effectiveness of Internal Audit in Risk Management at Public Sectors Enterprices. BVIMR Management Edge: 1-8.

Williamson, O. (1979) “The Governance of Contractual Relations”. Journal of Law and Economic: 2 (2).

Xiandong, W. (1997) “Development Trends and Future Prospects of Internal Audit”. Managerial Auditing Journal: 200-204.

Yee, C.S., Sujan, A., James, K., dan Leung, J.K.S. (2008) "Perceptions of Singaporean Internal Audit Customer Regarding the Role and Effectiveness of Internal Audit". Asian Journal of Business and Accounting, 1 (2): 147-174. 